Gökhan BAȘ, PhD

Niğde Ömer Halisdemir University, Faculty of Education

Niğde, Turkey. ${ }^{1}$

Cihad ȘENTÜRK ${ }^{2}$, PhD

Karamanoğlu Mehmetbey University, Faculty of Education, Karaman, Turkey.
Original scientific paper

UDC: 37.02

DOI: $10.5937 /$ IstrPed2002338B

\title{
PERCEPTIONS OF TEACHERS ABOUT THE CURRICULUM: A METAPHOR ANALYSIS
}

\begin{abstract}
The purpose of this research was to examine teachers' perceptions regarding the concept of curriculum through metaphor analysis. In this research, "phenomenology research design" was adopted. The participants of the research consisted of volunteering teachers $(n=261)$ working in ten public high schools in the province of Nigde, Turkey. The data obtained in the research were analysed through content analysis. According to the findings of the research, the teachers were seen to produce a total of 48 well-structured metaphors for curriculum concept, which were then grouped under five conceptual categories as guide, problem, system, complex structure, and need. Also, it was found that the teachers produced mostly positive metaphors about the concept of curriculum.
\end{abstract}

Keywords: curriculum, metaphors, phenomenological research, teachers.

\section{Introduction}

Curriculum is a century-old area of professional study in education (Wiles \& Bondi, 2007). The thoughts on the curriculum are relatively new (Ellis, 2013), yet the roots of it dates back to ancient Greek (Oliva \& Gordon, 2013). Although the concept of curriculum has been in existence since 1800 s (Pinar, Reynolds, Slattery, \& Taubman, 2006), "The Curriculum", written by Bobbitt (1918), is regarded as the beginning of the curriculum field. Later on, other books have pioneered the development of the field (Bosner, 1920; Charters, 1923; Counts, 1926; Taba, 1962; Tyler, 1949), bringing the debate about the definition of curriculum (Applebee, 1996).

The definition of the curriculum has shifted throughout the history of the field, beginning with Bobbitt (Pinar et al., 2006), making this process quite challenging for educators (Oliva \& Gordon, 2013). So far, people working in the field of curriculum have spent a lot of time and energy arguing about the definition of the curriculum (Ornstein \& Hunkins, 2012). In Latin, curriculum, which means an oval-shaped running track where Julius Caesar and his soldiers raced on horse cars in Rome (Oliva \& Gordon, 2013), came with time to mean traversing the

\footnotetext{
'gokhanbas51@gmail.com

2cihadsenturk@gmail.com
} 
course of study (Wiles \& Bondi, 2007). While the traditional educators defined the curriculum in a narrow framework, meaning syllabus, textbook, teacher guide, target-behaviours group, or list of materials (Oliva \& Gordon, 2013), by the mid-1950s it became increasingly evident that this concept was considered as a learning and teaching plan, and it was defined as "...all of the learning of students which is planned by and directed by the school to attain its educational goals" (Taba, 1962, p. 11), "...a course of study or plan for what is to be taught in an educational institution" (McNeil, 2005, p. 12). This position, popularised by Tyler and Taba, exemplifies a linear view of curriculum (Ornstein \& Hunkins, 2012). Since the 1960 s curriculum has been considered broadly as dealing with experiences of learners (Wiles \& Bondi, 2007), and defined as "a preplanned series of educational hurdles and an entire range of experiences a child has within the school" (Eisner, 2002, p. 26), and all the "experiences in the classroom [that are] planned and enacted" (Marsh \& Willis, 2003, p. 4). Looking at the definitions made, it appears that educators working in the field of curriculum have not reached a consensus on the definition of the concept of curriculum (Ornstein \& Hunkins, 2012). However, it is understood that, over time, many authors have defined the curriculum as a set of school experiences, it has been understood that this definition includes more than just "subjects", including "out-of-school" activities in school (Wiles, 2004). In this sense, the concept of curriculum has shifted from an understanding of a subject list to a structure that regulates the learning experiences of students. So, it can be claimed that the definition of curriculum has changed in response to social forces and expectations for the school (Wiles \& Bondi, 2007). Also, the way we define the concept of curriculum reflects our approach towards curriculum itself (Lunenberg \& Ornstein 2008). Hence, the beliefs of the people working in the field of curriculum can be claimed to be effective in making the definition of curriculum.

Although the concept of curriculum is defined in various ways, based on the viewpoints and/or the beliefs of educators (Wiles \& Bondi, 2007), curriculum is developed for the purposes of establishing a quality education system, sustaining the overall development of students and social and cultural values (Ornstein \& Hunkins, 2012). In order for the curriculum to be effective, all groups should be actively involved in curriculum development process (Oliva \& Gordon, 2013). Though the involvement of students, parents, inspectors, and school principals is important (Doll, 2008), teachers, who constitute one of the basic groups, should take an active role in curriculum development (Carl, 2005). Since the curriculum is put into practice by teachers in the classroom (Ornstein \& Hunkins, 2012), it is reasonable to benefit from their perceptions (Marsh \& Willis, 2003). The meaning attributed to the concept of curriculum by teachers includes important information for curriculum development (Yurdakul, 2015). So, the perceptions of teachers about the concept of curriculum can determine the effectiveness of teaching-learning process in a positive or negative way (Kyriakides, 1997). The perceptions of teachers about the curriculum is largely reflected in teaching and learning (Bantwini, 2010), influencing their decisions regarding instruction (Applefield, Huber, \& Moallem, 2001). In this sense, getting feedback in terms of teachers' perceptions about the concept of curriculum is considered to give some clues as how the curriculum is perceived and implemented in the classroom (Gultekin, 2017). The metaphors that teachers produce about the concept of curriculum can be used as an important data tool in curriculum development (Badley, \& van Brummelen, 2012). Since using metaphors to describe the concepts in schooling has been a productive data collection tool (Saban, 2006), it is considered to contribute much to the understanding of the concept of curriculum (Munby, 1990). Therefore, the purpose of the present phenomenological research was to examine the perceptions about the concept of curriculum for teachers working in high schools. In line with this purpose, the problem statement was posed as "What does the concept of curriculum mean to teachers?" In order 
to seek an answer to the research problem, the following sub-questions were addressed in the study:

(1) What metaphors do teachers use to describe the concept of curriculum?

(2) What conceptual categories can be derived from these metaphorical images?

\section{Theoretical framework}

\section{Use of metaphors in examining teacher perceptions}

Recent research reflects a shift towards qualitative methodology in understanding teachers' perceptions (Mahlios, Massengill-Shaw, \& Barry, 2010). In addition to surveys and scales, as widely used data collection tools, metaphors have also started to be preferred in gaining insights into the perceptions of teachers (Seferoglu, Korkmazgil, \& Olcu, 2009).

Metaphors are used to explain a complex phenomenon or event by likening to it to another phenomenon or event (Oxford et al., 1998). A metaphor, which is a process of expressing a definite meaning structure with another one (Kovecses, 2002), is described not with the concept, situation, or object itself, rather, it is described in an indirect way using another concept or object (Deant-Reed \& Szokolszky, 1993). Metaphorical thinking "involves making connections between two words or ideas that are not normally related but which share some commonly" (Miller, 2007, p. 102).

Metaphor, as a tool of "perception" (Arnett, 1999, p. 80), "is the understanding and experiencing of one kind of thing in terms of another" (Lakoff \& Johnson, 2003, p. 5). Thus, metaphor is not just figures of speech, but it constitutes an essential mechanism of the mind (Martinez, Sauleda, \& Huber, 2001). While metaphors are shaping the perceptions of teachers, they may influence their classroom practices (Mahlios, Massengill-Schaw, \& Barry, 2010). So, metaphoric expressions preferred by teachers portray their perceptions regarding teachingrelated issues (Bullough Jr \& Stokes, 1994). Perceptions not only influence how teachers think and practice in teaching, but also how they interpret the experience of teaching as well (Pajares, 1992). Use of metaphors as a methodology, therefore, serves as a means for framing and defining experiences of teachers (Neisser, 2003), influencing their classroom performance (Marshall, 1990).

There is a growing body of research claiming that metaphors can be used in examining teachers' perceptions about schooling, teaching, learning, and curriculum (Ben-Peretz, Mendelson, \& Kron 2003; Engin-Demir, 2007; Inbar, 1996; Mahlios, Massengill-Shaw, \& Barry, 2010; Martinez, Sauleda, \& Huber, 2001; Massengill, Mahlios, \& Barry, 2005; Saban, Kocbeker, \& Saban, 2007; Yurdakul, 2015). While metaphors can be used as an important data collection tool (Yob, 2003), they can assist researchers understand a phenomenon in a broader perspective. So, use of metaphors as a methodology in educational research may serve to identify teachers' mental images (Martinez, Sauleda, \& Huber, 2001), thus reflecting their classroom practice (Mahlios, Massengill-Schaw, \& Barry, 2010). Examining teachers' metaphorical perceptions may serve as a powerful tool to understand their teaching decisions and practices in classroom setting (Leavy, McSorley \& Bote, 2007). In examining teachers' metaphorical perceptions, their orientations towards future classroom decisions and practices can be foreseen (Gurney, 1995). In brief, using metaphors may contribute to better understand a phenomenon, acting as lenses through seeing it from a different theoretical perspective (Saban, Kocbeker, \& Saban, 2007). Therefore, metaphors can be used to elicit teachers' perceptions that cannot be obtained from the verbal implications of a spoken 
language (Moser, 2000).

\section{Metaphors about curriculum}

A review of research literature paints an ambiguous picture of metaphors about curriculum, each one providing different schemata (Akinoglu, 2017; Aykac \& Celik, 2014; Gultekin, 2013, 2017; Ozdemir, 2012; Yurdakul, 2015). The number of occurring curriculum metaphors in the research literature reveals the variety and complexity of the curriculum field (Brouwer, 2012). They are also "selective and they represent a part, but not the whole, of the phenomena they describe" (Weade \& Ernst, 1990, p. 133). Discovering metaphors which substitute the existing ones will generate new perceptions and interpretations (Seferoglu, Korkmazgil, \& Olcu, 2009). So, alternative metaphors are believed to contribute to a better understanding of curriculum.

The research literature provides us with a wide variety of metaphors produced regarding the curriculum. Keeping in mind that metaphors may be influenced by the surrounding culture or the nature of a country (Ibrahim, 2016), they reflect on how people see the world around them (Lakoff \& Johnson, 2003). For example, an agricultural society would feel more accustomed with growth metaphor, were an industrial society would adopt production metaphor (Ibrahim, 2016). This is also true for school settings, too. A teacher, working in a rural area, may perceive teaching as transmission of knowledge to students, while a teacher working in an urban area may consider it as facilitating learning of students. Although the metaphors produced regarding the curriculum are vast, they are mostly based on no empirical research, reflecting the viewpoints of authors. So, it is possible to make a distinction between the produced metaphors about curriculum as relying on no empirical research and relying on empirical research.

When the metaphors relying on no empirical research are reviewed, few metaphors are seen to be produced about curriculum. For instance, curriculum itself, meaning a course of study, is considered as a metaphor by Yero (2002), suggesting that it is including various concepts. As Kliebard (1972) defines the curriculum as a means of production as a metaphor, he considers it as a manufacturing process, symbolising the purpose of schooling. Also, Cook-Sather (2003), like Kliebard (1972), by referring to the root of curriculum, uses production metaphor, emphasising the role of curriculum in producing good in a factory. Further, Cook-Sather (2003) uses heeling metaphor for curriculum, defining it in which students are treated. Kliebard (1972) also uses journey metaphor for curriculum, in which students travel under the leadership of a teacher. In addition, Kliebard (1972) uses another metaphor growth for curriculum, likening it to a greenhouse where students stay to grow like plants. Moreover, Babtist (2002) expands growth metaphor into the garden metaphor, using aspects present both in curriculum and growth concepts such as senses, delight, and love. Besides, she claims that curriculum and garden are both similar, having mimetic constructions based on nature.

As the metaphors relying on empirical research are reviewed, a broad spectrum of metaphors is seen to be produced. For instance, while Gultekin (2013), identifying the metaphors used by prospective teachers, reached a number of 84 metaphors clustered under seven different conceptual categories as milestone, systematic structure, wide range, phenomenon which is open to developments, guide, shaper, and complex structure which creates problem. Besides, Aykac and Celik (2014) reached 174 metaphors produced by prospective teachers, mostly perceiving the curriculum as system, good quality product, defective, unusable and restrictive object, and uniform rules. Yurdakul (2015), by examining the perceptions of elementary school 
teachers, organised the findings under curriculum perception as a product of experience and the structural meaning of curriculum experience categories. More recently, Akinoglu (2017) found a total number of 107 metaphors, grouped under eight different conceptual categories as curriculum as guide, wide range, a source of problem, an organiser, a source of information, $a$ process, an indispensable element, and a means to achieve a particular outcome. Lastly, Gultekin (2017), by analysing the metaphorical perceptions of primary school teachers about curriculum, found a total number of 40 metaphors grouped under set of elements to be prepared carefully, a variable structure, directive, elements of oppression, multidimensional, a complex structure, and indispensable element categories.

In conclusion, it is seen that curriculum may be put forward in many different ways through metaphors. Therefore, it can be claimed that metaphors are very important tools in reflecting the points of view of teachers about curriculum. As the research literature is reviewed, curriculum is mostly perceived positive by teachers and prospective teachers. However, research literature also reports that teachers as well as prospective teachers attribute some negative metaphors to curriculum. As these metaphors are examined, it is claimed that teachers and prospective teachers tend to use modern metaphors, as well as the traditional ones. Also, when the metaphors relying on no empirical research are reviewed, it is suggested that the authors have used metaphors for curriculum, resembling the nature of the traditional education.

\section{Methodology}

\section{Research design}

In this study, phenomenology research design (Moustakas, 1994), which is one of the qualitative research designs (Creswell, 2012), was used in order to examine the perceptions of teachers about curriculum. Phenomenology research aims to gain an in-depth understanding of the meaning and nature of our daily experiences (Patton, 2002). A phenomenological study "describes the common meaning of several people's experiences of a concept or phenomenon" (Creswell, 2013, p. 76).

\section{Participants}

The participants of the research were consisted of volunteering teachers $(n=261)$ working in ten public high schools in the province of Nigde, Turkey. Of the participants, $56.70 \%(n=148)$ were men and $43.30 \%(n=113)$ were women in the research. With regard to occupational experience, $6(2.29 \%)$ teachers had $1-5$ years of experience, $53(20.30 \%)$ teachers had 6-10 years of experience, 103 (39.46\%) teachers had 11-15 years of experience, and 99 (37.93\%) teachers had more than 16 years of occupational experience.

\section{Data collection}

The data in the research were collected from the teachers working in public high schools. The data of the research were collected by visiting the schools within a period of ten days. The teachers were given a piece of paper with the sentence written on as "Curriculum is like..., because...". In order to determine the perceptions of the teachers about curriculum, each teacher was asked to complete the expression with a single metaphor and give a reason for the metaphor they produced. At the same time, the teachers were asked to write some demographic information (e.g., gender, occupational seniority, etc.) on the form distributed 
to them. Also, the teachers were given a fifteen-minute time to write the metaphors they used to represent the perceptions for curriculum. By using the word like, the participating teachers likened curriculum to something, and they explained what they likened the curriculum to by using the word because in the research.

\section{Data analysis}

The collected data were analysed through content analysis (Miles, Huberman, \& Saldana, 2013), which is used in qualitative research (Berg \& Lune, 2011). The main purpose of content analysis is to reach the concepts and relationships that can explain the collected data (Patton, 2002). Content analysis is used to analyse the collected data deeply and to represent new insights, perspectives, and reality from within the data (Krippendorf, 2013). The purpose of content analysis is to elucidate the concepts and the categories by analysing the data in depth (Gibbs, 2007).

The collected data in the research were resolved by following the steps suggested by Saban, Kocbeker, and Saban (2007). The steps used in analysing the metaphors achieved in the study were as: (a) naming / labelling, (b) classification (elimination and refinement), (c) reorganisation and compilation and category development, and (d) providing trustworthiness (Saban, Kocbeker, \& Saban, 2007). After creating an alphabetical list of the metaphors produced by the teachers, the metaphors were simple coded (Maxwell, 2013), eliminating the ones that were not based on a logical basis. The remaining raw data were reviewed to see (Patton, 2002), whether there were common features amongst the metaphors (Miles, Huberman, \& Saldana, 2013). Thus, each metaphor was divided into analytical parts and common features amongst the metaphors were sought (Bogdan \& Biklen, 2003). While a list was created with the compilation of the metaphors including a sample expression for each metaphor, the metaphors about curriculum were grouped together in terms of common features.

\section{Trustworthiness}

To sustain the trustworthiness, the research findings were given with thick descriptions, without making any common on them (Creswell, 2013). Besides, the conceptual categories were directed to an expert examination (Merriam, 2009), whether the findings were grouped under the right categories. Also, a participant confirmation for the excerpts were sought (Berg \& Lune, 2011), after the data were typewritten. In addition, a prolonged engagement was sustained with the teachers (Glesne, 2011), to understand the school climate and setting, contributing to the perceptions of teachers about curriculum. Lastly, a coder agreement was sought between two experts for the comparison of the categories created (Silverman, 2011), using the formula (reliability = consensus / consensus + dissidence $\mathrm{x} 100$ ), suggested by Miles, Huberman, and Saldana (2013). At the end of this comparison, an agreement rate of $94 \%$ was obtained, meaning that a desired consensus between the coders was sustained.

\section{Findings}

In this part of the research, metaphors in regard of curriculum produced by the teachers were analysed. Firstly, the metaphors acquired in the research were presented generally, and then the metaphors gathered under conceptual categories were given briefly. 


\section{Overall findings}

The teachers were seen to produce a total of 48 well-structured metaphors for curriculum concept. The top ten dominant metaphors in regard of curriculum produced by the teachers were as follows: guide $(f=32,12.26 \%)$, lantern $(f=19,7.27 \%)$, water $(f=14,5.36 \%)$, food $(f=13$, $\% 4.98)$, sun $(f=13,4.98 \%)$, book $(f=12,4.60 \%)$, trial board $(f=12,4.60 \%)$, maze $(f=10,3.83 \%)$, computer $(f=10,3.83 \%)$, and air $(f=9,3.45 \%)$. The information in terms of the frequency and percentage distribution of the metaphors produced by the teachers was given in Table 1.

Table 1. Frequency and percentage values regarding curriculum

\begin{tabular}{lcclcc}
\hline Metaphor & $f$ & $\%$ & Metaphor & $f$ & $\%$ \\
\hline air & 9 & 3.45 & lantern & 19 & 7.27 \\
book & 12 & 4.60 & life & 4 & 1.53 \\
breakdown & 3 & 1.15 & light & 6 & 2.29 \\
breath & 1 & 0.38 & manager & 1 & 0.38 \\
candle & 3 & 1.15 & maze & 10 & 3.83 \\
car motor & 2 & 0.76 & medicine & 3 & 1.15 \\
chaos & 1 & 0.38 & moon light & 2 & 0.76 \\
city plan & 1 & 0.38 & mother law & 1 & 0.38 \\
compass & 8 & 3.06 & north star & 4 & 1.53 \\
computer & 10 & 3.83 & plant & 1 & 0.38 \\
country & 1 & 0.38 & road map & 3 & 1.15 \\
DNA & 1 & 0.38 & robot & 1 & 0.38 \\
encyclopaedia & 10 & 3.83 & rule & 1 & 0.38 \\
exams & 1 & 0.38 & sand & 1 & 0.38 \\
factory & 3 & 1.15 & shepherd & 1 & 0.38 \\
failure & 1 & 0.38 & solar system & 1 & 0.38 \\
food & 13 & 4.98 & sun & 13 & 4.98 \\
guide & 32 & 12.26 & teacher & 7 & 2.68 \\
hard disc & 2 & 0.76 & torch & 2 & 0.76 \\
heart & 2 & 0.76 & traffic light & 1 & 0.38 \\
human body & 6 & 2.29 & tree & 2 & 0.76 \\
Internet & 1 & 0.38 & trial board & 12 & 4.60 \\
jigsaw & 8 & 3.06 & water & 14 & 5.36 \\
knot & 5 & 1.91 & water pipeline & 0.38 \\
\hline
\end{tabular}

Of the 48 metaphors produced in the research (see Table 1), 41 (85.42\%) were concrete and 7 (14.58\%) were abstract things. Of the 41 concrete metaphors (e.g., book, teacher, water pipeline), 7 (14.58\%) were about living things (e.g., teacher, tree, human body), whereas 41 were (85.42\%) about non-living things (e.g., food, lantern, torch). Of the 7 living metaphors, 4 (8.33\%) were about humans (e.g., teacher, shepherd, manager) and 2 (4.16\%) were about plants (e.g., tree, plant). The metaphors produced by the participating teachers were grouped under five conceptual categories in the research (see Table 2).

Table 2. Conceptual categories regarding curriculum

\begin{tabular}{lll}
\hline $\begin{array}{l}\text { Conceptual } \\
\text { Category }\end{array}$ & $\begin{array}{l}\text {-Participant } \\
\mathrm{n}(\%)\end{array}$ & \multicolumn{1}{c}{ Metaphors in regard of curriculum } \\
& - Metaphor & \\
& $f(\%)$ & Guide (32), lantern (19), sun (13), book (12), encyclopaedia (10), \\
Guide & $-128(49.04)$ & $\begin{array}{l}\text { compass (8), teacher (7), light (6), north star (4), road map (3), candle } \\
\text { (3), torch (2), moon light (2), mother law (1), Internet (1), manager (1), }\end{array}$ \\
\hline
\end{tabular}




\begin{tabular}{lll}
\hline & & shepherd (1), rule (1), solar system (1), traffic light (1) \\
\hline Problem & $-32(12.26)$ & $\begin{array}{l}\text { trial board (12), jigsaw (8), knot (5), breakdown (3), chaos (2), failure } \\
(1), \text { exams (1) }\end{array}$ \\
\hline \multirow{2}{*}{ System } & $-7(14.58)$ & -26(9.96) \\
& $-9(18.75)$ & $\begin{array}{l}\text { computer (10), human body (6), factory (3), heart (2), hard disc (2), } \\
\text { water pipeline (1), city plan (1), robot (1), solar system (1) }\end{array}$ \\
\hline Complex & $-17(6.51)$ & maze (10), life (4), car motor (2), DNA (1) \\
Structure & $-4(8.33)$ & \\
\hline \multirow{2}{*}{ Need } & $-44(16.86)$ & $\begin{array}{l}\text { water (14), food (13), air (9), medicine (3), tree (2), sand (1), plant (1), } \\
\text { country (1) }\end{array}$ \\
\hline
\end{tabular}

The metaphors produced regarding curriculum were gathered under five conceptual categories. These conceptual categories obtained in the research were as follows: guide, problem, system, complex structure, and need. The conceptual categories in terms of curriculum were explained in a broader extent in the following parts of the research, and each conceptual category was explained in detail.

Main conceptual categories

In this part of the research, the metaphors about curriculum concept produced by the participating teachers were examined under main conceptual categories.

Guide

In the research, the first conceptual category obtained in regard of curriculum concept was guide. A total of 128 teachers (49.04\%) in this category produced 20 well-structured metaphors (41.66\%). Of these metaphors, the first five dominant metaphors produced were; guide $(f=32$, $12.26 \%)$, lantern $(f=19,7.27 \%)$, sun $(f=13,4.98 \%)$, book $(f=12,4.60 \%)$, and encyclopaedia $(f=10$, $3.83 \%)$, respectively. When the opinions of the participating teachers were examined, it was seen that they likened the curriculum to things that guide people. For example, while a teacher likened curriculum to a guide as stating "Curriculum is like a guide, because we always have a look at it and find where to go" (M, 29, 7), another teacher likened curriculum to a teacher which tells what and how to do something to his or her students as stating "Curriculum is like a teacher, because it tells us how and what to do in teaching and learning process" (F, 32, 9). Also, another teacher, participated in the research, likened the curriculum to the moon light, as stating "Curriculum is like a moon light, because we can find our way easily by following it in teaching" (M, 35, 13).

Problem

The second conceptual category was problem. A total of 32 teachers $(12.26 \%)$ in this category produced 7 well-structured metaphors (14.58\%). Of these metaphors, the first five dominant metaphors produced were; trial board $(f=12,4.60 \%)$, jigsaw $(f=8,3.06 \%)$, knot $(f=5,1.91 \%)$, breakdown ( $f=3,1.15 \%)$, and chaos $(f=2,0.76 \%)$, respectively. When these metaphors produced by the teachers in this conceptual category were examined, it was understood that these metaphors are mostly things that people perceive as problems. For instance, while a teacher was seen to liken curriculum to a trial board as stating "Curriculum is like a trial board, because it is often changed by the Ministry of National Education" (F, 27, 5), another teacher was understood to liken the curriculum to a jigsaw as stating "Curriculum is like a jigsaw, because the authorities of the ministry change it whenever they want, without considering teachers' opinions" ( $\mathrm{F}, 40,19)$. Also, another teacher, participated in the research, likened the 
curriculum to a chaotic situation, as stating "Curriculum is like a chaos, because whenever it is changed, there occurs a chaos which teachers are in a dilemma and do not know how to implement it" $(M, 45,23)$.

\section{System}

The third conceptual category was system. A total of 26 teachers (9.96\%) in this category produced 9 well-structured metaphors (18.75\%). Of these metaphors, the first five dominant metaphors produced were; computer $(f=10,3.83 \%)$, human body $(f=6,2.29 \%)$, factory $(f=3$, $1.15 \%)$, heart $(f=2,0.76 \%)$, and hard disc $(f=2,0.76 \%)$. When these metaphors produced by the teachers in this conceptual category were examined, it was understood that these metaphors are mostly things containing a regular system in itself. This issue can also be seen in the following teacher opinions. For example, while a teacher likened curriculum to a computer as stating "Curriculum is like a computer, because it contains lots of elements which are closely related with each other" ( $M, 28,6)$, another teacher likened curriculum to a human body as stating "Curriculum is like a human body, because all parts in the curriculum are associated with each other and no part can work alone" (F, 31, 7). Also, another teacher, participated in the research, likened the curriculum to a factory, as stating "Curriculum is like a factory, because it has parts like in a factory and all parts work collaboratively to make production" (M, 42, 20).

\section{Complex structure}

The forth conceptual category was complex structure. A total of 17 teachers $(6.51 \%)$ in this category produced 4 well-structured metaphors (8.33\%). The metaphors produced in this category were; maze $(f=10,3.83 \%)$, life $(f=4,1.53 \%)$, car motor $(f=2,0.76 \%)$, and DNA $(f=1$, $0.38 \%)$. When these metaphors produced by the teachers in this conceptual category were examined, it was understood that these metaphors are mostly things that have a complex system or structure in it. For instance, while a teacher was seen to liken curriculum to a maze as stating "Curriculum is like a maze, because when you enter in it, you cannot find your way easily" ( $M, 38,16)$, another teacher was understood to liken the curriculum to life as stating "Curriculum is like life, because it has lots of complex areas that a person has to overcome everyday" $(\mathrm{F}, 33,9)$. Also, another teacher, participated in the research, likened the curriculum to a car motor, as stating "Curriculum is like a car motor, because when you open the bonnet, you cannot easily understand how it operates, because of all those cables and other things like those in it" (M, 29, 2).

\section{Need}

The last conceptual category was need. A total of 44 teachers $(16.86 \%)$ in this category produced 8 well-structured metaphors (16.66\%). Of these metaphors, the first five dominant metaphors produced in this category were; water $(f=14,5.36 \%)$, food $(f=13,4.98 \%)$, air $(f=9$, $3.45 \%)$, medicine $(f=3,1.15 \%)$, and tree $(f=2,0.76 \%)$. When these metaphors produced by the teachers in this conceptual category were examined, it was understood that these metaphors are mostly things that humans basically need. This issue can also be seen in the following teacher opinions. For example, while a teacher likened curriculum to water as stating "Curriculum is like water, because education and instruction need it so much. Without it, education cannot survive by itself" ( $F, 42,20)$, another teacher likened curriculum to food as stating "Curriculum is like food, because education cannot live without curriculum. Curriculum is the basic food of the education system" $(F, 48,26)$. Also, another teacher, participated in the research, likened the curriculum to air, as stating "Curriculum is like air, because as people cannot live without breathing it, education cannot live without curriculum. It is the core need of the education system" $(M, 34,11)$. 


\section{Discussion}

The present research examined the metaphorical perceptions of the teachers about curriculum. Several important findings were obtained in line with the purpose of the research, explaining the teachers' perceptions about the curriculum. Firstly, in order to explain a complex phenomenon such as the curriculum in a broader perspective, many metaphors are needed. Defining the curriculum merely with a metaphor is not possible (Ross, 2000), since curriculum as a field of study is complex and dynamic (Ornstein \& Hunkins, 2012; Wiles \& Bondi, 2007). Therefore, the teachers participated in the research were seen to use a large number of metaphors to describe a complex and multidimensional phenomenon such as curriculum. The teachers produced a total number of 48 distinct metaphors about the curriculum, conceptualised in five categories. The top ten dominant metaphors regarding the curriculum were as; guide, lantern, water, food, sun, book, trial board, maze, computer, and air, respectively. In the study, the vast majority of the metaphors were positive, confirming the findings of previous research (Akinoglu, 2017; Gulkekin, 2013, 2017; Ozdemir, 2012). Nevertheless, the research literature has also revealed contrasting metaphors (Aykac \& Celik, 2014; Tasdemir \& Tasdemir, 2011), claiming that teachers and prospective teachers do not have a clear understanding about the curriculum.

Also, the teachers, who participated in the research, used various metaphors to reflect their conceptualisations about the curriculum. The metaphors produced by the teachers in terms of the curriculum were conceptualised under five categories as guide, problem, system, complex structure, and need. Within these categories, the teachers produced the most numerous metaphors under guide and need, respectively. This may mean that the teachers consider the curriculum as a thing, in which they are to follow on like textbooks. This finding also implies strict curriculum fidelity of teachers (Bumen, Cakar, \& Yildiz, 2014), making their autonomy in classroom practice weaker. Previous research supports this finding that teachers and prospective teachers (Akinoglu, 2017; Gogebakan-Yildiz, 2017; Izalan \& Gogebakan-Yildiz, 2018; Gultekin, 2013; Yurdakul, 2015), as well as the pioneering scholars working in the field of curriculum in Turkey perceive the curriculum as a guide (Orten \& Erginer, 2016). On the contrary, the conceptual category in which the teachers produced a minimum number of metaphors was complex structure. This finding could mean that the teachers may have hardness to understand the structure of the curriculum. This issue may be related to teachers' knowledge levels (Basturk \& Donmez, 2011), making them fail to understand the basic system and principles of the curriculum. Recent research also reveals that teachers as well as prospective teachers perceive the curriculum as having a complex structure (Gultekin, 2013, 2017), confirming the present finding. Furthermore, the teachers produced positive metaphors in the conceptual categories of guide, system, and need for the curriculum, while they generated negative metaphors in problem and complex structure categories, respectively. Teachers, by producing positive metaphors in guide, system, and need categories, tend to have a positive attitude towards the curriculum itself. Since positive attitudes towards curriculum is considered important (Shriner, Schlee, \& Libler, 2010), they may ease teachers' acceptance of the curriculum and implement it in practice accordingly. In contrast, negative attitudes may also influence the acceptance of the curriculum, resulting in teachers fail to implement it in practice. Defining the curriculum with problem and complex structure may influence the educational reform acts (Fullan, 2001), making the implementation of the curriculum unsuccessful.

Secondly, the metaphors regarding the curriculum produced by the teachers may be shaped by many factors. In particular, teacher beliefs (Cronin-Jones, 1991; Handal \& Harrington, 2003), 
past educational experiences (Pajares, 1992; Rodgers \& Scott, 2008), recent curriculum policy (Archbald \& Porter, 1994), and teachers' role in curriculum development (Carl, 2005) may have a significant influence on the perceptions of teachers about the curriculum. Since beliefs are important components in understanding conceptualisations about schooling (Muijs \& Reynolds, 2002), they may shape teachers' perceptions about the curriculum (Cheung \& Wong, 2002) and drive their classroom teaching practices (Pajares, 1992; Richardson, 1996). For example, teachers adopting progressive and existentialist educational beliefs suggest negative metaphors about the curriculum, seeing it as a problem (Izalan \& Gogebakan-Yildiz, 2018). This claims that teachers' educational beliefs play an important role in shaping their metaphorical perceptions about the curriculum. Also, teachers' past educational experiences may have an influence on how they perceive the curriculum, making them gain insight into the curriculum positively or negatively. As the previous research reports that earlier educational experiences have an influence on the perceptions (Richardson, 1996), they may shape how teachers perceive the curriculum. For example, Tarman (2012) found that prospective teachers' perceptions about teaching were modified because of the negative experiences they had in the secondary school setting. In this research, it was suggested that negative situations that prospective teachers experienced played a significant role in shaping their perceptions about teaching. Besides, recent curriculum policy may be the other factor underlying teachers' perceptions about the curriculum (Kruger, Won, \& Treagust, 2013). Frequent changes in curriculum may have a significant influence on teachers' negative perceptions about the curriculum (Assuncao-Flores, 2005). Teachers, who are facing with frequent curriculum changes, may have negative perceptions about the curriculum. For example, the teachers in Turkey, as experiencing several curriculum changes in the past two decades, suggest negative metaphors about the curriculum (Izalan \& Gogebakan-Yildiz, 2018), associating it with things related to problem. Lastly, teachers' control over the curriculum and their role in curriculum development may well determine how they perceive the curriculum (Kyriakides, 1997). Teachers' role is considered important (Oliva \& Gordon, 2013), for making the curriculum more effective in practice (Wiles \& Bondi, 2007). Thus, lack of adequate teacher involvement in curriculum development may affect educational reform initiatives to be unsuccessful (Fullan, 2001). This is particularly true in terms of teachers having limited role in curriculum development, resulting in negative perceptions about the curriculum. In this sense, teachers' role in curriculum development is considered crucial (Hewitt, 2006), making them reflect positive or negative perceptions about the curriculum.

Thirdly, teachers coming from distinct cultural backgrounds may suggest different metaphorical images, defining the curriculum. For example, Cook-Sather (2003) conceptualised the curriculum as production metaphor, with making reference to Kliebard (1972). Both authors, while associating the curriculum with production, symbolise schools with factories. Also, Kliebard (1972) uses the growth metaphor for the curriculum, resembling the curriculum to the greenhouse where students are educated to develop their potential. Similarly, Babtist (2002), by expanding the growth metaphor, uses the garden metaphor for the curriculum. Unlike these metaphors, the present research produced different metaphors in defining the curriculum. This research produced no metaphors similar to those authors, defining the curriculum as production, growth, and garden. The underlying reason for the teachers using metaphors related to guide -the most popular category- may stem from the Turkish culture, as it has needed leaders to direct the society throughout the history (Zurcher, 2010), such as in the eastern cultures (Ben-Peretz, Mendelson, \& Kron, 2003). 
Lastly, researchers and policy makers can use metaphors as valuable cognitive tools to examine teachers' philosophy of education beliefs regarding the curriculum. Thus, teachers can be asked to evaluate the curriculum, by providing metaphors. Because teachers may be hesitant to answer the interview questions or reluctant to involve in surveys, making teachers use metaphors in a short time may contribute well to the understanding of the curriculum reflected in classroom practice. For instance, Aykac and Celik (2014) used metaphors to examine teachers' perceptions about the curriculum. The findings of the research suggested that teachers perceive the curriculum mostly as having a good outlook, but as a hollow object, restrictive, and uniform rules. Based on these findings, it can be claimed that teachers see the curriculum ineffective. So, taking these data through metaphors, an effective curriculum can be put forward for classroom practice, reflecting the teachers' views.

\section{Notes}

This paper was presented at the X. International Congress on Educational Research, held in 2018 in Nevşehir, Turkey.

\section{References}

Akinoglu, O. (2017). Pre-service teachers' metaphorical perceptions regarding the concept of curriculum. International Journal of Instruction, 10(2), 263-278.

Applebee, A. W. (1996). Curriculum as conservation. Chicago, IL: University of Chicago Press.

Archbald, D. A., \& Porter, A. C. (1994). Curriculum control and teachers' perceptions of autonomy and satisfaction. Educational Evaluation and Policy Analysis, 16 (1), 21-39.

Arnett, R. C. (1999). Metaphorical guidance: Administration as building and renovation. Journal of Educational Administration, 37(1), 80-89.

Assuncao-Flores, M. (2005). Teachers' views on recent curriculum changes: Tensions and challenges. Curriculum Journal, 16(3), 401-413.

Aykac, N., \& Celik, O. (2014). Comparison of the metaphorical perceptions of teachers and prospective teachers in regard of curriculum. Education and Science, 39(173), 328340.

Badley, K., \& Van Brummelen, H. (Eds.). (2012). Metaphors we teach by: How metaphors shape what we do in classrooms. Eugene, OR: Wipf and Stock Publishers.

Bantwini, B. D. (2010). How teachers perceive the new curriculum reform: Lessons from a school district in the Eastern Cape Province, South Africa. International Journal of Educational Development, 30 (1), 83-90.

Basturk, S. \& Donmez, G. (2011). Examining pre-service teachers' pedagogical content knowledge with regard to curriculum knowledge. International Online Journal of Educational Sciences, 3 (2), 743-775.

Ben-Peretz, M., Mendelson, N., \& Kron, F. W. (2003). How teachers in different educational context view their roles. Teaching and Teacher Education, 19, 277-290.

Berg, B. L., \& Lune, H. (2011). Qualitative research methods for the social sciences (8th ed.). Upper Saddle River, NJ: Pearson.

Bobbitt, F. (1918). The curriculum. Boston: Houghton Mifflin.

Bogdan, R. C., \& Biklen, S. K. (2003). Qualitative research for education: An introduction to theory and methods (4th ed.). Boston, MA: Allyn \& Bacon.

Bosner, F. G. (1920). The elementary school curriculum. New York, NY: Macmillan. 
Brouwer, E. (2012). Curriculum as a journey toward wisdom. In K. Badley \& H. V. Brummelen (Eds.), Metaphors we teach by: How metaphors shape what we do in the classroom (pp. 68-88). Eugene, OR: Wipf and Stock.

Bullough Jr, R. V., \& Stokes, D. K. (1994). Analyzing personal teaching metaphors in preservice teacher education as a means for encouraging professional development. American Educational Research Journal, 31 (1), 197-224.

Bumen, N. T., Cakar, E., \& Yildiz, D. G. (2014). Curriculum fidelity and factors affecting fidelity in the Turkish context. Educational Sciences: Theory \& Practice, 14 (1), 219-228.

Carl, A. (2005). The "voice of the teacher" in curriculum development: A voice crying in the wilderness. South African Journal of Education, 25 (4), 223-228.

Charters, W. W. (1923). Curriculum construction. New York, NY: Macmillan.

Cheung, D., \& Wong, H. W. (2002). Measuring teacher beliefs about alternative curriculum designs. The Curriculum Journal, 13 (2), 225-248.

Cook-Sather, A. (2003). Movements of mind: The matrix, metaphors, and re-imagining education. Teachers College Record, 105 (6), 946-977.

Counts, G. S. (1926). The senior high school curriculum. Chicago, IL: University of Chicago Press.

Creswell, J. W. (2012). Educational research: Planning, conducting, and evaluating quantitative and qualitative research (4th ed.). New York, NY: Pearson.

Creswell, J. W. (2013). Qualitative inquiry and research design: Choosing among five approaches (3rd ed.). Thousand Oaks, CA: Sage.

Cronin-Jones, L. L. (1991). Science teacher beliefs and their influence on curriculum implementation: Two case studies. Journal of Research in Science Teaching, 28 (3), 235-250.

Deant-Read, C. H., \& Szokolszky, A. (1993). Where do metaphors come from? Metaphor and Symbolic Activity, 8 (3), 227-242.

Doll, R. C. (2008). Curriculum improvement: Decision making and process (9th ed.). Boston: Allyn \& Bacon.

Eisner, E. W. (2002). The educational imagination (3rd ed.). Colombus, OH: Merrill.

Ellis, A. K. (2013). Exemplars of curriculum theory. New York, NY: Routledge.

Engin-Demir, C. (2007). Metaphors as a reflection of middle school students' perceptions of school: A cross-cultural analysis. Educational Research and Evaluation, 13 (2), 89-107.

Fullan, M. (2001). The new meaning of educational change (3rd ed.). New York, NY: Teachers College Press.

Gibbs, G. (2007). Analyzing qualitative data. Thousand Oaks, CA: Sage.

Glesne, C. (2011). Becoming qualitative researchers: An introduction (4th ed.). Boston, MA: Pearson.

Gogebakan-Yildiz, D. (2017). An analysis of attitudes and metaphoric perceptions towards the course of curriculum development in education. International Journal of Curriculum and Instructional Studies, 7(14), 113-130.

Gultekin, M. (2013). The metaphors that primary education prospective teachers use regarding curriculum. Education and Science, 38 (169), 126-141.

Gultekin, M. (2017). Metaphoric perceptions of primary school teachers on the concept of curriculum. Journal of Education and Future, 11, 51-73.

Gurney, B. F. (1995). Tugboats and tennis games: Preservice conceptions of teaching and learning revealed through metaphors. Journal of Research in Science Teaching, 32 (6), 569-583.

Handal, B., \& Herrington, A. (2003). Mathematics teachers' beliefs and curriculum reform. Mathematics Education Research Journal, 15 (1), 59-69. 
Hewitt, T. W. (2006). Understanding and shaping curriculum: What we teach and why. Thousand Oaks, CA: Sage.

Ibrahim, A. M. (2016). Curriculum metaphors. The Eurasia Proceedings of Educational \& Social Sciences, 4, 385-390.

Inbar, D. (1996). The free educational prison: Metaphors and images. Educational Research, 38(1), 77-92.

Izalan, Z., \& Yildiz, D. G. (2018). A comparative study of classroom teachers' educational beliefs and metaphorical perceptions of curriculum. International Online Journal of Educational Sciences, 10 (4), 199-214.

Kliebard, H. M. (1972). Metaphorical roots of curriculum design. Teachers College Record, 73 (3), 402-403.

Kovecses, Z. (2002). Metaphor: A practical introduction. New York: Oxford University Press.

Krippendorf, K. (2013). Content analysis: An introduction to its methodology (3rd ed.). Thousand Oaks, CA: Sage.

Kruger, M., Won, M., \& Treagust, D. F. (2013). Teachers' perceptions on the changes in the curriculum and exit examinations for biology and human biology. Australian Journal of Teacher Education, 38 (3), 41-58.

Kyriakides, L. (1997). Primary teachers' perceptions of policy for curriculum reform in mathematics. Educational Research and Evaluation, 3 (3), 214-242.

Lakoff, G., \& Johnson, M. (2003). Metaphors we live by. Chicago: University of Chicago Press.

Leavy, A. M., McSorley, F. A., \& Bote. L. A. (2007). An examination of what metaphor construction reveals about the evolution of preservice teachers' beliefs about teaching and learning. Teaching and Teacher Education, 23 (7), 1217-1233.

Lunenberg, F., \& Ornstein, A. C. (2008). Educational administration: Concepts and practices (5th ed.). Belmont, CA: Wadsworth.

Mahlios, M., Massengill-Shaw, D., \& Barry, A. (2010). Making sense of teaching through metaphors: A review across three studies. Teachers and Teaching: Theory and Practice, 16 (1), 49-71.

Marsh, C. J., \& Willis, G. (2003). Curriculum: Alternative approaches, ongoing issues (3rd ed.). Colombus, $\mathrm{OH}$ : Merrill.

Marshall, H. H. (1990). Beyond the workplace metaphor: The classroom as a learning setting. Theory into Practice, 29 (2), 94-101.

Martinez, M. A., Salueda, N., \& Huber, G. L. (2001). Metaphors as blueprints of thinking about teaching and learning. Teaching and Teacher Education, 17, 965-977.

Massengill, D., Mahlios, M., \& Barry, A. (2005). Metaphors and sense of teaching: How these constructs influence novice teachers. Teaching Education, 16 (3), 213-229.

Maxwell, J. A. (2013). Qualitative research design: An interactive approach (3rd ed.). Thousand Oaks, CA: Sage.

McNeil, J. (2005). Contemporary curriculum: In thought and action (6th ed.). New York, NY: Wiley.

Merriam, S. B. (2009). Qualitative research: A guide to design and implementation. San Francisco, CA: Jossey-Bass.

Miles, M. B., Huberman, A. M., \& Saldana, J. M. (2013). Qualitative data analysis: A methods sourcebook (3rd ed.). Thousand Oaks, CA: Sage.

Miller, J. P. (2007). The holistic curriculum (2nd ed.). Toronto: University of Toronto Press.

Moser, K. S. (2000). Metaphor analysis in psychology: Method, theory, and fields of application. Forum: Qualitative Social Research, 1 (2), Available from http://www.qualitative-research.net/fqs-texte/2-00/2-0omoser-e.htm. (10.02.2016)

Moustakas, C. (1994). Phenomenological research methods. Thousand Oaks, CA: Sage. 
Muijs, D., \& Reynolds, D. (2002). Teachers' beliefs and behaviors: What really matters? The Journal of Classroom Interaction, 37 (2), 3-15.

Munby, H. (1990). Metaphorical expressions of teachers' practical curriculum knowledge. Journal of Curriculum and Supervision, 6 (1), 18-30.

Neisser, J. U. (2003). The swaying form: Imagination, metaphor, embodiment. Phenomenology and the Cognitive Sciences, 2, 27-53.

Oliva, P. F., \& Gordon, W. R. (2013). Developing the curriculum (8th ed.). Boston, MA: Pearson.

Ornstein, A. C., \& Hunkins, F. P. (2012). Curriculum: Foundations, principles, and issues (6th ed.). Boston, MA: Pearson.

Orten, D., \& Erginer, E. (2016). Metaphoric perceptions of the pioneering scholars in the field of curriculum development in Turkey in regard of curriculum development in education. Uluslararasi Toplum Araștirmalari Dergisi, 6, 387-414.

Oxford, R. L., Tomlinson, S., Barcelos, A., Harrington, C., Lavine, R. Z., \& Saleh, A. (1998). Clashing metaphors about classroom teachers: Toward a systematic typology for the language teaching field. System, 26, 3-50.

Ozdemir, M. S. (2012). Metaphoric perceptions of prospective teachers regarding the concept of curriculum. Journal of Theoretical Educational Science, 5 (3), 369-393.

Pajares, M. F. (1992). Teachers' beliefs and educational research: Cleaning up a messy construct. Review of Educational Research, 62, 307-332.

Patton, M. Q. (2002). Qualitative research and evaluation methods (3rd ed.). Thousand Oaks, CA: Sage.

Pinar, W. F., Reynolds, W. M., Slattery, P., \& Taubman, P. M. (2006). Understanding the curriculum: Introduction to the study of historical and contemporary curriculum discourses (5th ed.). New York, NY: Peter Lang.

Richardson, R. (1996). The role of attitude and beliefs in learning to teach. In J. Sikula, T. Buttery, \& E. Guyton (Eds.), Handbook of research on teacher education (2nd ed., pp. 102-119). New York: Macmillan.

Rodgers, C. R., \& Scott, K. H. (2008). The development of the personal self and professional identity in learning to teach. In M. Cochran-Smith, S. Freiman-Nemser, D. J., McIntyre, \& K. E. Demers (Eds.), Handbook of research on teacher education (3rd ed., pp. 732-755). New York: Routledge.

Ross, A. (2000). Curriculum: Construction and critique. London: Falmer Press.

Saban, A. (2006). Functions of metaphor in teaching and teacher education: A review essay. Teaching Education, 17 (4), 299-315.

Saban, A., Kocbeker, B. N., \& Saban, A. (2007). Prospective teachers' conceptions of teaching and learning revealed through metaphor analysis. Learning and Instruction, 17, 123139.

Seferoglu, G., Korkmazgil, S., \& Olcu, Z. (2009) Gaining insights into teachers' ways of thinking via metaphors. Educational Studies, 35 (3), 323-335.

Shriner, M., Schlee, B. M., \& Libler, R. (2010). Teachers' perceptions, attitudes and beliefs regarding curriculum integration. The Australian Educational Researcher, 37 (1), 51-62.

Silverman, D. (2011). Interpreting qualitative data (4th ed.). Thousand Oaks, CA: Sage.

Taba, H. (1962). Curriculum development: Theory and practice. New York: Harcourt, Brace and World.

Tarman, B. (2012). Prospective teachers' beliefs and perceptions about teaching as a profession. Educational Sciences: Theory \& Practice, 12 (3), 1964-1973.

Tasdemir, M., \& Tasdemir, A. (2011, April). Teachers' metaphors on K-8 curriculum in Turkey. Paper presented at the 2nd International Conference on New Trends in Education and Their Implications, Antalya, Turkey. 
Tyler, R. W. (1949). Basic principles of curriculum and instruction. Chicago, IL: University of Chicago Press.

Weade, R., \& Ernst, G. (1990). Pictures of life in classrooms, and the search for metaphors to frame them. Theory into Practice, 29, 133-140.

Wiles, J. (2004). Curriculum essentials (2nd ed.). Boston, MA: Allyn \& Bacon.

Wiles, J., \& Bondi, J. (2007). Curriculum development: A guide to practice (7th ed.). Upper Saddle River, NJ: Pearson/Merrill Prentice Hall.

Yero, J. L. (2002). Teaching in mind: How teacher thinking shapes education. Hamilton, MT: MindFlight Pub.

Yob, I. M. (2003). Thinking Constructively with Metaphors. Studies in Philosophy and Education, $22,127-138$.

Yurdakul, B. (2015). Perceptions of elementary school teachers concerning the concept of curriculum. Educational Sciences: Theory \& Practice, 15 (1), 125-139.

Zurcher, E. J. (2010). Turkey: A modern history. London: I. B. Tauris.

\section{Biographical notes:}

Gokhan Bas is an associate professor in the Department of Curriculum \& Instruction, Faculty of Education, Nigde Omer Halisdemir University. His research interests include curriculum and instruction, teaching-learning process, educational research methodologies, and classroom assessment.

Cihad Senturk is an assistant professor in the Department of Curriculum \& Instruction, Faculty of Education, Karamanoglu Mehmetbey University. His research interests include curriculum and instruction, teaching-learning process, and primary teaching. 